\title{
Tibial muscular dystrophy
}

INSERM

\section{Source}

INSERM. (1999). Orphanet: an online rare disease and orphan drug data base. Tibial muscular dystrophy. ORPHA:609

Tibial muscular dystrophy (TMD) is a distal myopathy characterized by weakness of the muscles of the anterior compartment of lower limbs, appearing in the fourth to seventh decade of life. 